\title{
EVALUATION OF LIGNIN CONTENT OF SOYBEAN SEED COAT STORED IN A CONTROLLED ENVIRONMENT ${ }^{1}$
}

\author{
FRANCISCO CARLOS KRZYZANOWSKI², JOSÉ DE BARROS FRANCA NETO², JOSE MARCOS GONTIJO MANDARINO² AND MILTON \\ KASTER ${ }^{2}$
}

\begin{abstract}
Breeding soybean for high seed quality is an important approach for developing cultivars for tropical regions, and the lignin content in the seed coat is one of the screening parameters for this trait. Considering that many breeding lines are evaluated in each growing season using the presently recommended method for lignin determination, a long period is required for the evaluation of the whole breeding program. This time limitation may influence lignin content assessment, if lignin is degraded during storage. This research reported was designed to determine whether lignin was degraded in the seed coat of soybean seed cultivars stored for one year in a controlled environment $\left(10^{\circ} \mathrm{C}\right.$ temperature and $50 \%$ air relative humidity). Seeds of 12 selected soybean cultivars that had a range in seed coat lignin content were evaluated. Seeds were hand harvested just after physiological maturity and evaluated for seed coat lignin content at harvest and after one year of storage in a cold room $\left(10^{\circ} \mathrm{C}\right.$ and $\left.50 \% \mathrm{RH}\right)$. The lignin content in seed coats differed significantly among cultivars in both analyses, but for both results the sequence of cultivar classification and the lignin content values of each cultivar did not change. A regression analysis of lignin content at harvest and after one year of storage indicated a direct relationship between both lignin determinations suggesting no differences between the lignin content of each cultivar due to prolonged storage $\left(r^{2}=0.98^{* * *}\right)$.
\end{abstract}

This indicates that the lignin determination in the soybean seed coat can be performed over a long time period without any bias due to change in its content.

Index terms: Glycine max, plant breeding, seed quality, seed storage

\section{AVALIAÇÃO DO CONTEÚDO DE LIGNINA DO TEGUMENTO DE SEMENTE DE SOJA ARMAZENADA EM AMBIENTE CONTROLADO}

RESUMO - O melhoramento de soja para alta qualidade de semente é um importante enfoque para o desenvolvimento de cultivares para as regiões tropicais, e o conteúdo de lignina no tegumento da semente é um parâmetro para seleção, visando essa característica. Considerando que muitas linhagens são avaliadas em cada safra, utilizando a metodologia recomendada para a determinação de lignina, um longo período de avaliação é requerido para atender todo o programa de melhoramento. Se a lignina se degradar durante esse período de armazenamento, o tempo total de avaliação do programa pode ser uma limitação a influenciar nos resultados. O presente estudo foi planejado para avaliar se a lignina sofre degradação durante um ano de armazenamento em ambiente controlado (10 ${ }^{\circ} \mathrm{C}$ de temperatura e $50 \%$ de umidade relativa do ar). Sementes de 12 cultivares selecionadas com distintos conteúdos de lignina no tegumento foram avaliadas. As sementes foram colhidas logo após o ponto de maturidade fisiológica ter sido atingido (R7) e avaliadas para o conteúdo de lignina na época de 
colheita e um ano após terem sido armazenadas em câmara fria e seca ( $10^{\circ} \mathrm{C}$ e $50 \%$ UR). O conteúdo de lignina no tegumento significativamente diferiu entre as cultivares nas duas épocas de análises, mas em ambas os resultados referentes à classificação e ao conteúdo de lignina de cada cultivar não alteraram. A análise de regressão do conteúdo de lignina na colheita e após um ano de armazenamento indicou uma relação direta entre ambas determinações, sugerindo não haver diferenças no conteúdo de lignina de cada cultivar devido ao armazenamento prolongado $\left(\mathrm{r}^{2}=0.98^{* * *}\right)$. Isto significa que a determinação do conteúdo de lignina no tegumento da semente de soja pode ser realizada durante um longo período de tempo sem que possam ocorrer erros devido à alteração no seu percentual.

Termos para indexação: Glycine max, melhoramento de planta, qualidade de semente, armazenamento de semente.

\section{INTRODUCTION}

Lignin is a natural complex phenolic polymer, which is important for mechanical support, water transport, and defense in vascular plants (Lewis and Yamamoto, 1990; Campbell and Sederoff, 1996). In soybean, seed coat lignin plays an important role in physical and physiological seed qualities (Alvarez et al., 1997). The soybean seed coat is very thin and low in lignin content, and provides little protection to the fragile radicle that lies in a vulnerable position directly beneath the seed coat (Agrawal and Menon, 1974; Gupta et al., 1973, França Neto and Henning, 1984).

Breeding soybean for high seed quality is an important approach for developing cultivars for tropical regions, and the lignin content in the seed coat was found to be one of the screening parameters for this trait (Krzyzanowski, 1998). Seeds of soybean cultivars with seed coat lignin content above $5.0 \%$ are less prone to mechanical damage (Alvarez et al., 1997).

Considering the large number of breeding lines evaluated in each growing season and the sulphuric acid method presently recommended for lignin determination in soybean seed coat (Krzyzanowski et al., 2001), a long period will be required for the evaluation of the whole breeding program. This limitation can be a factor interfering in the selection criteria if variation in lignin content occurs during the storage period. The research reported herein was designed to study the occurrence of variation in the amount of lignin content in the seed coat of soybean cultivars evaluated at maturity and after one year of storage in a controlled environment $\left(10{ }^{\circ} \mathrm{C}\right.$ and $\left.50 \% \mathrm{RH}\right)$.

\section{MATERIALS AND METHODS}

Seeds of 12 soybean cultivars (Bossier, Davis, Doko,
FT-2, FT-10, IAC-2, IAC-8, IAS 5, Parana, Paranagoiana, Santa Rosa, and Savana) produced at Londrina County (latitude 23 11' 50" S), State of Parana, Brazil, during the 1996/1997 growing season were evaluated for seed coat lignin content. These cultivars were selected because of their known seed coat lignin content.

Plants were hand harvested just after physiological maturity (R7), when seed moisture content was $20 \%$ and brought to a ventilated warehouse, where the seeds were left to dry to a moisture content of $13 \%( \pm 0.5)$ dry weight basis. Pods were hand threshed to avoid mechanical damage and the resulting seeds were evaluated for seed coat lignin content at harvest and after one year storage in a cold room at $10^{\circ} \mathrm{C}$ and $50 \%$ relative humidity.

A randomized complete block design experiment with 12 treatments (cultivars), with four field replications and three laboratory sub-samples was used to determine the lignin content in the soybean seed coat. The lignin determination method utilizes sulfuric acid as the digesting agent. The sulfuric acid method was described by Bailey (1967) and was modified by Vidaure (1991). Further adaptations were done for soybean seed coat lignin determination (Alvares et al. 1997). The analytical method used for lignin determination was described by Krzyzanowski et al, (2001).

Seeds were initially immersed in water, for approximately $12 \mathrm{~h}$, to separate the seed coat from the cotyledons. The seed coats were dried in an oven for $16 \mathrm{~h}$, at $105^{\circ} \mathrm{C}$ and stored in a desiccator at room temperature. For each field replication of each cultivar, three sub-samples of $250 \mathrm{mg}$ of seed coat were weighed, and transferred to $250 \mathrm{~mL}$ volumetric flasks. Fifty $\mathrm{mL}$ of ethanol $80 \%(\mathrm{v} / \mathrm{v})$ were added to each flask and the flask was heated on an electric hot plate under reflux for $10 \mathrm{~min}$. The sample was then filtered through filter paper (Schleicer and Schull 1989). The filtrates were discarded and the residues submitted again to the same process. The 
residues were transferred to $250 \mathrm{~mL}$ glass flasks and $100 \mathrm{~mL}$ of deionized distilled water added and heated under reflux for $10 \mathrm{~min}$. and subsequently filtered. The filtrates were discarded and the residues again treated in the same way. The residues were transferred to $250 \mathrm{~mL}$ glass flasks, $100 \mathrm{ml}$ of $0.5 \%(\mathrm{v} / \mathrm{v})$ was added, refluxed for 2 hours, filtered, and the filtrates discarded. $1.0 \mathrm{~N}$ sulfuric acid $(100 \mathrm{~mL})$ solution was added to the residues into glass flasks, under reflux for $2 \mathrm{~h}$, and filtered through a porcelain gooch crucible (40 to 60 micra diameter) under vacuum.

The residues retained in the crucible were washed with $50 \mathrm{~mL}$ of acetone p.a and transferred to beakers, into which $20 \mathrm{~mL} \mathrm{72 \%} \mathrm{(v/v)} \mathrm{sulfuric} \mathrm{acid} \mathrm{solution} \mathrm{was} \mathrm{added.}$ The beaker was covered with a watch glass. After 12 h., the residues were transferred to glass flasks using $100 \mathrm{~mL}$ distilled deionized water heated for $2 \mathrm{~h}$. under reflux, and filtered through a porcelain gooch filtering crucible under vacuum. The residues (lignin) retained on the crucible were washed with $200 \mathrm{~mL}$ distilled deionized water. The crucibles containing the residues were dried in an oven at $105^{\circ} \mathrm{C}$ for 6 h., cooled in a glass desiccator with silica and determined gravimetrically the content of lignin (residue) in the seed coat.

An analysis of variance of seed coat lignin content before and after storage was carried out. The Duncan multiple comparison mean test was applied at the level of 5\% probability. A regression analysis was performed between the values of lignin content in the seed coat at harvest and after one year in storage.

\section{RESULTS AND DISCUSSION}

The seed coat lignin content differed significantly among the cultivars, and did not significantly change after the 12-month storage period (Table 1). The results of lignin content in the seed coat and the ranking of the cultivars agree with those previously observed by Alvarez et al. (1997). The stability of seed coat lignin even in storage can be explained by the insolubility and complexity of the lignin polymer. These characteristics make lignin resistant to degradation by most microorganisms (Campbell and Sederoff, 1996).

TABLE 1. Seed coat lignin content (\%) of 12 soybean cultivars determined at harvest and after one year at cold storage $\left(10^{\circ} \mathrm{C}\right.$ and $\left.50 \% \mathrm{RH}\right)$. Embrapa Soybean. 2002.

\begin{tabular}{|c|c|c|c|}
\hline \multirow[b]{2}{*}{ CULTIVAR } & \multicolumn{2}{|c|}{ Seed Coat Lignin Content (\%) } & \multirow[b]{2}{*}{ MEAN } \\
\hline & Harvest & After Cold Storage $^{1}$ & \\
\hline Doko & $6.20 \mathrm{a}^{2}$ & $6.27 \mathrm{a}$ & $6.24 \mathrm{a}$ \\
\hline FT-2 & 6.19 a & $6.24 \mathrm{a}$ & $6.22 \mathrm{a}$ \\
\hline Santa Rosa & $5.75 \mathrm{ab}$ & $5.65 \mathrm{ab}$ & $5.70 \mathrm{~b}$ \\
\hline IAC-8 & $5.72 \mathrm{ab}$ & $5.72 \mathrm{ab}$ & $5.72 \mathrm{~b}$ \\
\hline IAS 5 & $5.72 \mathrm{ab}$ & $5.52 \mathrm{~b}$ & $5.62 \mathrm{~b}$ \\
\hline Paraná & $5.56 \mathrm{ab}$ & $5.54 \mathrm{~b}$ & $5.55 \mathrm{~b}$ \\
\hline FT-10 & 5.28 bc & 5.41 bc & $5.34 \mathrm{~b}$ \\
\hline Bossier & 5.28 bc & 5.26 bc & $5.27 \mathrm{~b}$ \\
\hline Paranagoiana & $4.79 \mathrm{~cd}$ & $4.84 \mathrm{~cd}$ & $4.81 \mathrm{C}$ \\
\hline Davis & $4.62 \mathrm{~cd}$ & $4.77 \mathrm{~cd}$ & $4.70 \mathrm{~cd}$ \\
\hline Savana & 4.36 & 4.22 & 4.29 de \\
\hline IAC-2 & 4.21 & 4.17 & 4.19 \\
\hline MEAN & $5.31 \mathrm{~A}$ & $5.30 \mathrm{~A}$ & -- \\
\hline
\end{tabular}

${ }^{1}$ Period of cold storage $\left(10^{\circ} \mathrm{C} / 50 \% \mathrm{RH}\right): 12$ months.

${ }^{2}$ Means followed by the same letter per column do not differ statistically by the Duncan's

Multiple Range Test at the 5.0\% probability level. 
The regression analysis performed between the lignin content at harvest and after one year of cold storage (Figure 1) resulted in a direct relationship for both lignin sets of data, with a $\mathrm{r}^{2}$ value of 0.98 . This result, in addition to the observed equation $(y=1.002 x-0.0164)$, mean that both sets of lignin content are approximately the same. This fact reinforces the analysis of variance reported above, indicating that there was no change in seed coat lignin content of all cultivars after 12 month cold storage $\left(10^{\circ} \mathrm{C} / 50 \% \mathrm{RH}\right)$.

FIGURE 1. Regression analysis between seed coat lignin content of 12 soybean cultivars at harvest and after one year cold room storage $\left(10^{\circ} \mathrm{C}\right.$ and 50\% RH). Embrapa Soybean. 2002.

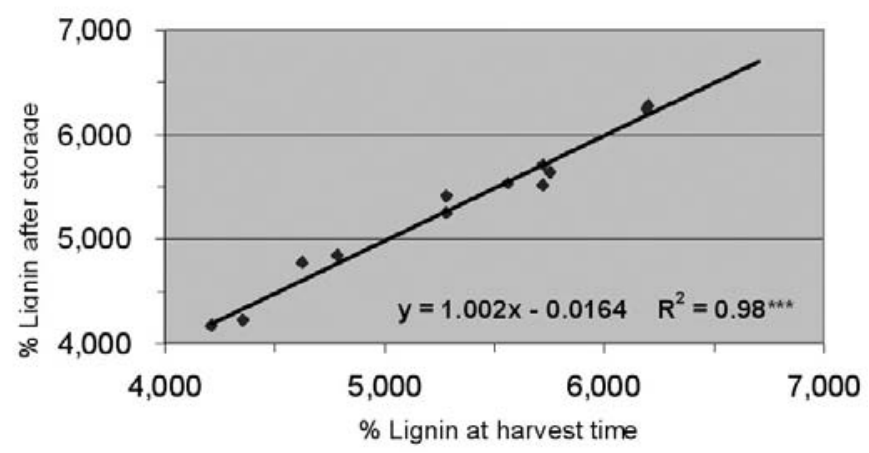

It is concluded that the lignin content of soybean seed coat is stable when stored in a cold room and that its quantity can be determined during a 12-month period without any significant change in its content. This information will allow soybean breeders to use seed coat lignin content is a selection criteria for the improvement of seed quality of soybean grown in tropical environments.

\section{ACKNOWLEDGMENTS}

CNPq - National Council of Scientific and Technological Development supported this study with a grant. We wish to thank Luciano A. Felisbino for his technical assistance in lignin determinations.

\section{REFERENCES}

AGRAWAL, P.K.; MENON, K. Lignin content and seed coat thickness in relation to seed coat cracking. Seed Research,
New Delhi, n.2, p.64-66, 1974.

ALVAREZ, P.J.C.; KRZYZANOWSKI, F.C.; MANDARINO, J.M.G.; FRANÇA-NETO, J.B. Relationship between soybean seed coat lignin content and resistance to mechanical damage. Seed Science and Technology, Zurich, n.25, p.209-214. 1997.

BAILEY, R.W. Quantitative studies of ruminant digestion II. Loss of ingested carbohydrates from the reticule rumen. Journal of the Agriculture Research, New Zealand, n.10, p.1532, 1967.

CAMPBELL, M.M.; SEDEROFF, R.R. Variation in lignin content and composition. Plant Physiology, New York, n.110, p.3-13, 1996.

GUPTA, P.C., MILLER, D.A.; HITTLE, C.N. Note on the effect of threshing on seed damage, seed vigor and germination in two soybean varieties. Indian Journal of Agricultural Science, New Delhi, n. 43, p.617-618, 1973.

FRANÇA NETO, J.B.; HENNING, A.A. Qualidades fisiológica e sanitária de sementes de soja. Londrina: EMBRAPA-CNPSo, 1984. 39 p. (EMBRAPA -CNPSo. Circular Técnica, 9).

KRZYZANOWSKI, F.C. Relationship between seed technology research and federal plant breeding programs. Scientia Agrícola, Piracicaba, n. 55, p.83-87, 1998.

KRZYZANOWSKI, F.C.; FRANÇA-NETO, J.B., MANDARINO, J.M.G.; KASTER, M. Comparison between two gravimetric methods to determine the lignin content in soybean seed coat. Seed Science and Technology, Zurich, n. 29, p.619-624, 2001.

LEWIS, N.G.; YAMAMOTO, E. Lignin: occurrence, biogenesis and biodegradation. Annual Review of Plant Physiology. Plant Molecular Biology, Palo Alto, v.41, p.455-496, 1990.

VIDAURE, J.C. Otimização do processo de pré-tratamento do bagaço de cana- de-açúcar com peróxido de hidrogênio alcalino e sua hidrólise por enzima celulolíticas. 1991. 130 f. Tese (Mestrado) - Universidade Estadual de Londrina, 